Tér és Társadalom 4. 1990:3-4: 185-190.

\title{
A KÖRNYEZETI VÁLTOZÁSOK, AZ EMBER ÉS KELET-EURÓPA \\ Egy történeti ökológiai konferencia tapasztalatai
}

\section{RÁCZ LAJOS}

A European Science Foundation Igazgató Tanácsa 1987 végén határozta el Az utolsó jégkorszakot követổ európai éghajlati változások és az ember címú kutatási program elindítását. Az alapítvány anyagi támogatásával szervezổdött meg 1989 tavaszán Bad Homburgban a European Association for Environmental History. ${ }^{1}$ A társaság elsốdleges célja, hogy a történeti korok természeti környezetének állapotáról, annak változásairól szóló információkat ősszegyũjtse egy európai környezet- illetve éghajlattörténeti adatbank számára. Az európai történeti ökológiai információs rendszer alapját a svájci C. Pfister által kialakított éghajlattörténeti adatbank, a CLIMHIST alkotja, amelynek döntóen közép-európai területekrôl származó történeti forrásai már jelenleg is négy (angol, francia, német, olasz) nyelven hozzáférhetốk. ${ }^{2}$ A European Association for Environmental History vezetôi a forráslehetôségek felmérése, és a különbözô európai régiókban született éghajlattörténeti kutatási eredmények összevetése céljából konferenciát hívtak össze 1990. március 1-3. között Mainzban. A nyugat-németországi workshop mindenekelốtt a történeti kutatás eredménýeinek fóruma volt, amit a konferencia címe is jelzett: European Climate Reconstructed from Historical Documents. A filológus történészek mellett azonban igen nagy számban adtak elố a környezeti változások problémájával foglaikozó más diszciplínák, így a humán geográfia, a geofizika, az oceanológia, a klimatológia és az informatika kutatói is.

A környezettörténeti információk feltárása és feldolgozása mellett a konferencia másik központi témája volt az éghajlati változások hatása a gazdaság múködésére, valamint a társadalmidemográfiai folyamatok alakulására. Különösen aktuálissá tette az ökológiai impulzusok problémáját az a tény, hogy a történeti idôk két igen jelentôs éghajlati-környezeti vâltozása épp az újkor, illetve a jelenkor idején ment, megy végbe. A keresztény európai civilizáció számára másfélezer éves története során kétségtelenül a legkomolyabb ökológiai kihívás ${ }^{3}$ a , ,kis jégkorszak" (1550-1860) éghajlatromlása volt. Hasonlóképpen jelentôs, bár végsố eredményét tekintve nehezen prognosztizálható hatást gyakorol a modern civilizáció fejlődésére századunk globális felmelegedése.

Az ipari forradalmat megelôző korokban lényegesen egyszerú́bb kimutatni a környezeti változások hatását a gazdaság múködésére és a demográfiai folyamatokra. Labrousse ${ }^{4}$ nyomán a gazdaságtörténet kutatói a tradícionális társadalmak kríziseit a mezôgazdasági termések változásaiból vezették le, Braudel megfogalmazása szerint a kora újkori világban , ,.. a termések ritmusa, minôsége és elégtelensége mozgatja az anyagi létet". ${ }^{5}$ Az indusztrializációt követôen a technika fejlôdése nagyságrendekkel növelte a gazdálkodás hatékonyságát, a közlekedési-szállítási hálózat kiépülése pedig nagyban csökkentette a lokális ellátási válságok kialakulásának lehetôségét. Az ökológiai bázis átmeneti ,,leértékelởdése” után, századunk , ,hatvanas éveiben került újra az érdeklôdés homlokterébe a természeti környezet és annak változása. A 
jelenkori gazdasági növekedés ökológiai korlátozottságáról vallott nézetek legnagyobb hatású összefoglalása a Növekedés határai címú Római Klub-tanulmány volt. ${ }^{6}$

Igen nagy érdeklődést váltott ki a konferencia harmadik napján Pfister elổadása egy példa nélküli gazdaságtörténeti vizsgálatról, amelynek során a svájci kutató regressziós elemzés segítségével megkísérelte kimutatni az éghajlati változások hatását a gabonaárak alakulására Svájc területén 1525 és 1979 közöttt (1. ábra).

Pfister véleménye szerint az ellátási válságok kialakulását ökológiai szempontból a következổ tényezổk egybeesése idézhette elổ: csapadékos ôsz, korai tél, hideg és havas tavasz, csapadékos nyár (különösen fontos az esổs július). A gyenge termések idôjárási okai közül mindenekelổtt az utolsó két tényezổnek, a hưvös tavasznak és a csapadékos nyárnak volt döntổ jelentôsége.

Amennyiben az iparosodás elốtti évszázadokban több, a mezôgazdaság számára kedvezổtlen idôjárású év követte egymást, akkor a kontinentális Európa belsổ területein ${ }^{8}$ csaknem elkerülhetetlenül bekövetkezett az élelmezési válság, éhínségektổ, járványoktól és áremelkedésektôl kísérve. Az árak emelkedését Pfister véleménye szerint a következố okokra lehet visszavezetni: 1. éghajlati anomáliák elôidézte gyenge termések;

2. gazdasági és/vagy politikai okok (háború, embargó);

3. ökológiai változások és a gazdasági-politikai tényezốk interferenciája.

Pfisternek az éghajlat- és gazdaságtörténeti adatok statisztikai elemzése során a 16. és a 19. század között 9 ellátási válságot sikerült kvantitatív módszerekkel ökológiai okokra visszavezetni $(1569-1574,1586-1589,1594-1597,1627-1630,1688-1694,1714-1715,1769-1771$, 1816-1817, 1845-1855). A vizsgált négy és fél évszázadon belül 1570 és 1630 között figyelhetố meg a legerốsebb szinkronitás az éghajlatváltozások és az árak ingadozása között. Ez a koincidencia döntôen az igen drasztikus ökológiai változásokra vezethetố vissza. A 16. század derekán kezdốdổ globális éghajlatromlás, a ,,kis jégkorszak" általános lehũlése következtében a tenyészidốszak a korábbiaknál lényegesen hũvösebb és csapadékosabb lett, az alpi gleccserek ekkor több száz métert nyomultak elổre. ${ }^{9}$ Az ökológai hatások az esetek döntố többségében egyéb gazdasági-politikai okokkal együtt voltak képesek tartós áremelkedéseket, és ennek következtében a létfeltételek jelentôs romlását elôidézni. Ilyen módon az 1620 tájăn kezdődő áremelkedést ugyan néhány rossz termésư év indította el, de a tendencia felerõsödése már egyértelmủen a harmincéves háború következménye volt.

Igen érdekes vitát indított el a 18. századi áremelkedések kérdése. Abban egyetértettek a kutatók, hogy a svájci gabonaárak növekedése a túlnépesedés által elöidézett általános európai tendencia része volt. Az 1700-as évek példátlanul nagy népességnövekedésének értelmezése viszont már erốsen megosztotta a konferencia résztvevôiit. Bonyolította a problémát az is, hogy Biraben kutatásai szerint ez a szokatlanul gyors demográfiai növekedés nem korlátozódott Európára. 

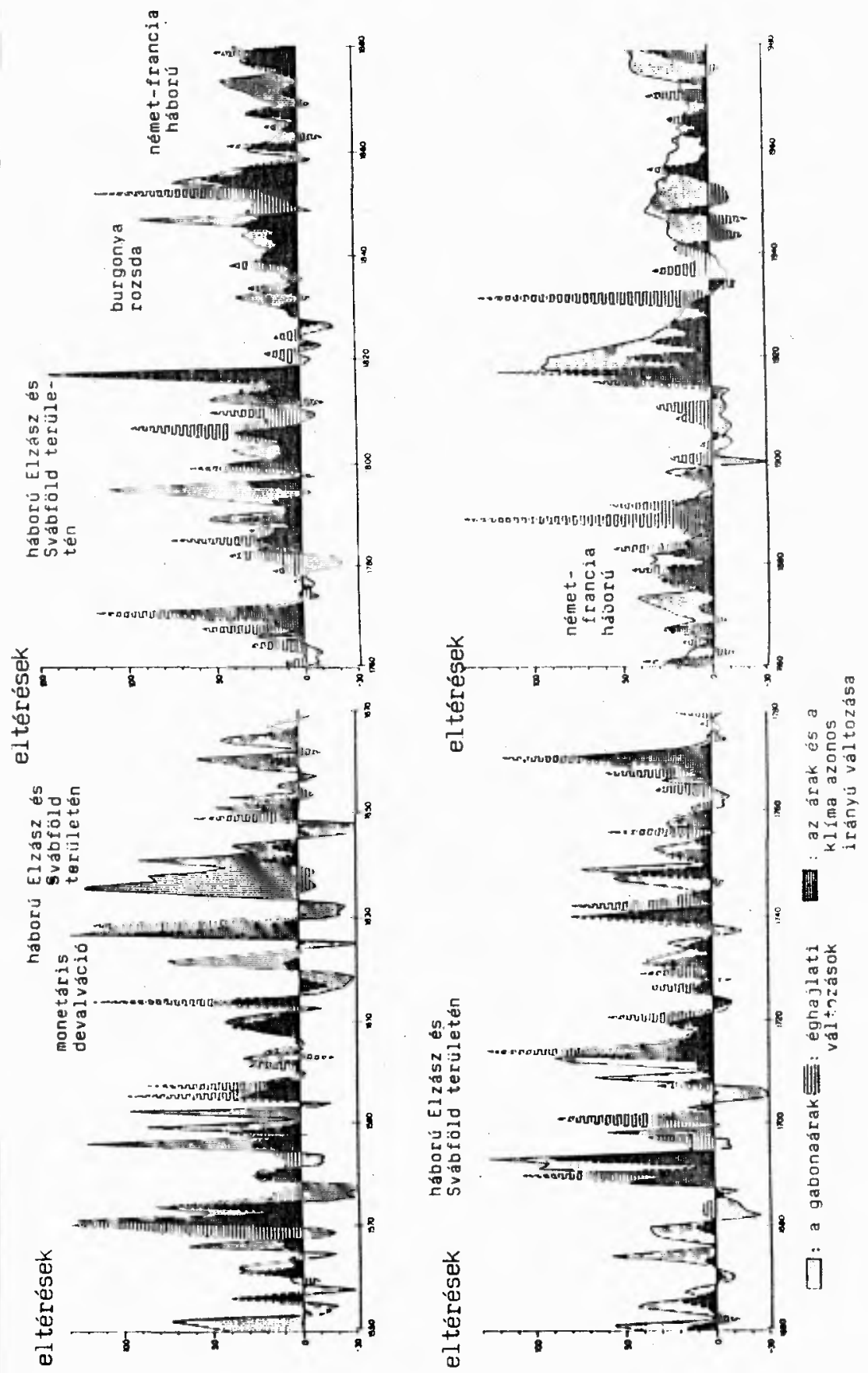

$\infty$
0
0
$\vdots$
5
5
5

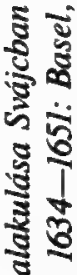

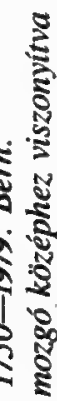

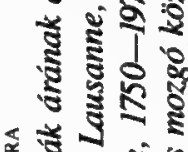


Rácz Lajos : A környezeti változások, az ember és Kelet-Európa

Egy történeti ökológiai konferencia tapasztalatai

Tér és Társadalom 4. évf. 1990/3-4. 185-190. p.

TÉT 1990-3-4

1. TÁBLÁZAT

A kora újkori civilizációk népességének növekedése a 15-18. század folyamán

(Dupaquier, J. 1988)

Európa (a Szovjetúnió jelenlegi területei nélkül):

1 - J. N. Biraben becslése

2 - C. Mac Evedy és R. Jones becslése

\begin{tabular}{rrrccc}
\hline \multicolumn{2}{c}{ Európa } & Kína & Észak-Amerika & Dél-Amerika \\
\hline 1500 & 67 & 69 & & & \\
1600 & 89 & 85 & & & \\
1650 & & 88 & & & 10 \\
1700 & 95 & 100 & 150 & & 19 \\
1750 & 111 & 114 & & 5 & \\
1800 & 146 & 144 & 310 & 5 & \\
\hline
\end{tabular}

A demográfiai expanzió egyetemességét az Annales-körhöz tartozó történészek egy része azzal magyarázta, hogy az ember nem csupán a történelem alanya, hanem túl ezen egy jelenleg a Földön domináns biológiai faj is, amelynek sajátos evolúciós ritmusa van. ${ }^{10}$ Az éghajlattörténettel foglalkozó kutatók az elổbbinél valamivel ,, földhözragadtabb" teóriával álltak elô. Véleményük szerint a ,,kis jégkorszak” 'éghajlatromlásának három súlypontja között (a 16-17. század fordulója, a 17. század vége és a 19. század elsổ fele), a 18. század volt a demográfiai növekedés számára a legalkalmasabb idôszak. Amikor pedig a 19. század elsô felében az ökológiai viszonyok újra kedvezôtlenné váltak, akkor már az indusztrializáció következtében az európai népesség egyre nagyobb része függetlenedett a termések éves ritmusától. ${ }^{11}$ A 19 . századot követôen Svájcban az élelmezési válságok , tradicionális”, idôjárási okokra visszavezethetổ típusa mindössze egyetlen alkalommal, 1917-18 idején fordult elổ, amikor az éghajlati tényezốk primátusát a háborús elszigeteltség biztosította.

A környezet és az ember, az ökológiai bázis és a gazdasági-társadalmi folyamatok kapcsolatrendszerének múködését a Climatic Research Unit kutatói kísérelték meg formalizálni (2. ábra).

1. szint

2. $\operatorname{szint}$

3. szint

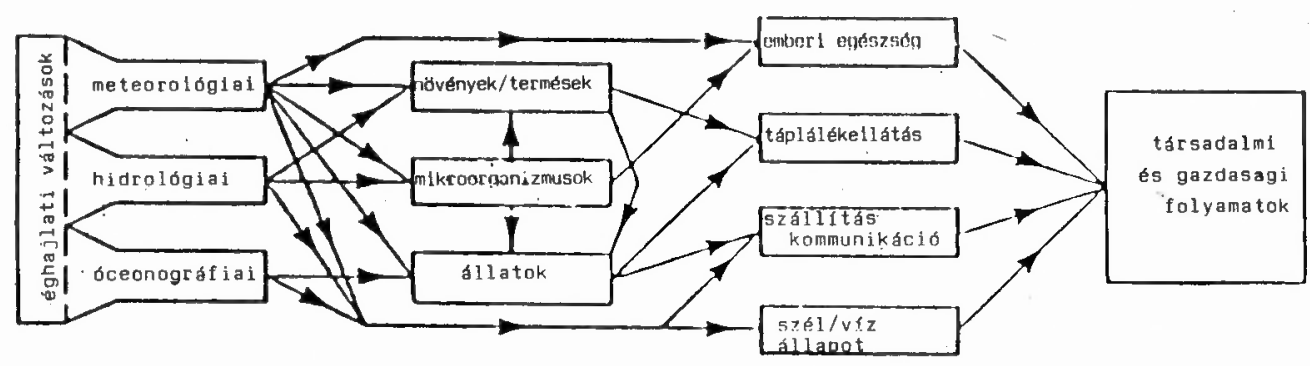

2. $A B R A$

Az éghajlati-környezeti változások hatása a fizikai-biológiai folyamatokra, az élố rendszerekre és a gazdaság; valamint a társadalom változásaira (Wigley, T. M. - Ingram, M. J. - Farmer, G. 1981) 
Rácz Lajos : A környezeti változások, az ember és Kelet-Európa

Egy történeti ökológiai konferencia tapasztalatai

Tér és Társadalom 4. évf. 1990/3-4. 185-190. p.

A történeti ökológiai modell elkészítése során az Ingram-Farmer-Wigley angol szerzőhármas mindenekelỗtt az éghajlati-környezeti impulzusok pályáját vizsgálta. ${ }^{12} \mathrm{Az}$ elemzés szerint az atmoszférában végbemenô változások meteorológiai, hidrológiai és oceanográfiai jelenségek formájában gyakorolnak hatást az élổ rendszerekre (elsổ szint). Ezek a fizikai-biológiai impulzusok nagyban meghatározzák a társadalom életjelenségeit, egy adott populáció élelmiszerellátását, annak egészségi állapotát, a szállítás és a kommunikáció térbeni lehetôségeit (második szint). Az ancien régime idején az ökológiai impulzusokat ,,elszenvedổ' társadalom, a történeti ökológia kutatói szerint, két csoportra osztható (harmadik szint). Arra a kisebbségre, amely gazdasági-politikai helyzetébôl adódóan függetleníteni tudta magát a termések és az árak ingadozásától, és minden körülmények között a ,túlélési küszöb" fölött maradt. S a társadalom többségére, amelynek egzisztenciáját viszont a gazdaság mindenkori teljesítóképessége határozta meg. Az európai társadalmak ezen számosabb része csak az iparosodást követôen került tartósan, nagy biztonsággal a , túlélési küszöb" fölé. ${ }^{13}$

Igen különös közjáték zavarta meg a workshop utolsó, összegzổ napjának munkáját. Az elốadások végeztével Pfister és Fenzel kérte az egybegyũlt kutatókat, hogy régiónként vegyék sorra a történeti korok éghajlati-környezeti változásait dokumentáló természettudományos és történeti forrásokat, majd a régiók szerinti szekciókban készítsenek ajánlásokat azok feldolgozásához. A gyanútlan szervezők négy nagy európai régiót határoltak el ebbő̉ a célból, nevezetesen Északnyugat-Európát, Mediterrán-Európát, Közép-Európát és Kelet-Európát. A soros kávészünet végeztével a kelet-európai szekcióban egyedül az orosz résztvevô foglalta el a helyét. A lengyel és a magyar kutatók határozottan kijelentették, hogy ốk minden szempontból KözépEurópához tartoznak. Ekkor a csehszlovákok, jelezve kompromisszumkészségüket, kimentek a két szekció tárgyalóhelyiségét összekötô folyosóra. A konferencián résztvevố észt klimatológus nem bocsátkozott a Kelet- és Közép-Európa közötti határvonalat tisztázó, esetleg bizonytalan kimenetelứ vitába, inkább a balti közösség jogán csatlakozott az északnyugat-európai szekcióhoz. Némi tanácstalanság után a szervezõk a kelet-európai munkacsoport megalakításának gondolatát elvetették. Az összegzố vita így egy kibổvített közép-európai szekcióban indulhatott meg, amelyben már ,teljes jogú tagként" vett részt az orosz kutató is.

\section{Jegyzetek}

1 A European Association for Enviromental History levélcíme: Prof. C. Pfister, Historisches Institut Universität Bern, Engehaldenstrasse 4, $\mathrm{CH}-3012$ Bern.

2 Pfister, C. Climhist - A Weather Data Bank for Switzerland 1525 to 1863, Berne.

3 Ökológiai változásokon az indusztrializációt megelôzốen, a fogalmat szûken értelmezve, csak a természeti környezet öntörvényũ, belsổ változásait értem.

4 Labrousse, C. E. - Braudel, F. (1970) Histoire économique et sociale de la France, Paris.

${ }_{5}$ Braudel, F. (1966) La Méditerranée et le monde mediterranéen à l'époque de Philippe II, Paris.

6 Meadows, D. H. - Meadows, D. L. - Randers, J. - Behrens, W. (1972) Limits to Growth, New York.

7 Pfister e témában korábban publikált munkái: Pfister, C. (1985) Bevölkerung, Klima und Agrarmodernisierung 1525-1860, Berne.

Pfister, C. (1988) Fluctuations climatiques et prix céréaliers en Europe du $\mathrm{XVI}^{e}$ au $\mathrm{XX}^{e}$ siécle, Annales E. S. C. 25-53. 0 .

${ }^{8}$ Eu rópa tengerparti területein a gyenge termések már a késố középkor ịdején sem vezettek okvetlenül ellátási válsághoz, hiszen itt a nagy tömegũ gabona közvetítésére képes tengeri kereskedelem segítségével a regionális különbségek többnyire kiegyenlítôdtek (Bailtikum-Németalföld). A kontinens bèlsố területein viszont, a szállítás nehéz 
és költséges voltából adódóan, a zárt helyi piacok struktúrája egészen a vasút megjelenéséig alapvetổ realitás maradt.

"Pfister, C. a következô módon foglalta össze a ,,kis jégkorszak" (1550-1860) legfontosabb jellemzổit:

a. A téli hónapok hosszú távon 0,7 fokkal hidegebbek és $5 \%$-kal szárazabbak, a tavaszi hónapok 0,3 fokkal hidegebbek és $5 \%$-kal szárazabbak voltak.

b. Az éghajlat változékonysága nagyobb volt.

c. Azonos típusú téli, tavaszi és nyári periódusok követték egy mást több év folyamán, aminek következtében hatásuk összeadódott. A klímaváltozások az évszakok közötti különbözó kombinációkban jelennek meg. A nyári periódusok általában nem voltak szignifikánsan hidegebbek a 20. századi átlagnál, de fôként a 16. és 17. században egy kevéssel csapadékosabbak voltak. Az ôszi hớmérséklet 1670 tájáig a jelenlegi közép körül váltakozott, 1670 és 1920 között a hômérséklet egy kicsit alacsonyabb és a csapadék valamivel bốségesebb volt, mint az utóbbi hat évtized folyamán.

10 Dupaquier, J. (1988) Population et famille (kézirat), elhangzott az Instituto Internazionale di Storia Economica ,,Francesco Dantini” konferenciáján, Pratoban.

11 Pfister, C. (1988) i. m.

12 Wigley, T. M. L. - Ingram, M. J. - Farmer, G. (1981) Climate and History, Cambridge.

13 Goubert, P. (1960) Beaunais et le Beauvasis de 1600 à 1730, Paris. 